\title{
Beszámoló az MTA Regionális Tudományos Bizottságának és Településtudományi Bizottságának üléséről
}

\author{
(2006. július 18.)
}

\section{HARDI TAMÁS}

A Magyar Tudományos Akadémia Regionális Tudományos Bizottsága és Településtudományi Bizottsága egy közös összejövetelt tartott 2006. július 18-án az MTA Országház utcai épületében, a Jakobinus teremben. A gyưlést megtisztelte jelenlétével Magyarország miniszterelnöke, Gyurcsány Ferenc, valamint Lamperth Mónika önkormányzati és területfejlesztési miniszter asszony. Az ülés célja volt, hogy a tudomány és politika közösen gondolkodjon a regionalizáció, decentralizáció és területfejlesztési problémák kérdésköréröl. A tanácskozást Rechnitzer János, a Regionális Tudományos Bizottság, valamint Szirmai Viktória a Településtudományi Bizottság elnöke vezette le.

A gyülés kezdetén Rechnitzer János köszöntötte a Miniszterelnököt és a Belügyminisztert, majd bemutatta a két bizottságot, ismertette munkájukat. Jelentős eseményként értékelte, hogy ez az első alkalom, amikor Magyarország miniszterelnöke felkeresi a két bizottságot. Lampert Mónika miniszter asszonnyal a kapcsolat már hagyományosnak mondható, hiszen részt vett már bizottsági ülésen, s más tekintetben is többször értekezett a bizottsággal vagy annak tagjaival, $\mathrm{s}$ ismeri a Magyar Regionális Tudományi Társaság munkáját is.

$\mathrm{Az}$ összejövetel célját értékelve elmondta, hogy a Tudományos Akadémiát sok jogtalan és jogos bírálat érte a közelmúltban, de az Akadémia egy fontos helye a tudományos kommunikációnak, $s$ jelentös a szerepe az ország fejlődési irányainak meghatározásában. Az MTA dolga, hogy a tudományos eredményeket biztosítsa a politikusok számára ehhez a modernizációhoz.

A magyar modernizáció egy fontos fordulóponthoz érkezett. A területi fejlödésnek meghatározó szerepe van a megújulásban. Ha a regionális és településhálózati folyamatokat fel lehet gyorsítani, a decentralizációt végre lehet hajtani, akkor a modernizáció is sikeres lesz.

Az elnöki bevezető után Gyurcsány Ferenc értékelte a regionális és települési szakma, valamint a politika kapcsolatát. Elismerésként kiemelte, hogy más szakmai területektől eltéröen a regionális kérdésekkel és területfejlesztéssel foglalkozó szakma és közélet ma elég világosan és pontosan képes megmondani azt, hogy milyen típusú politikai döntésekkel lehet az ország javát szolgálni. A politikusoknak csak az lenne a dolguk, hogy a szakmai konszenzusok bázisán meghozzák a döntéseket. A regionalizmus és a területfejlesztés kérdéseiben a szakma a politika elött jár. Nem minden szakterületen ez a helyzet. Itt viszont nincs meg a politikai többség a szakmai igazságok érvényesítéséhez. A politikai események értékelése 
kapcsán kijelentette, hogy a decentralizáció parlamenti elutasítása miatt a kívánatos állapot felé egy bonyolultabb úton kell elindulni, meg kell találni azokat a lehetöségeket, amelyek a decentralizáció irányába hatnak.

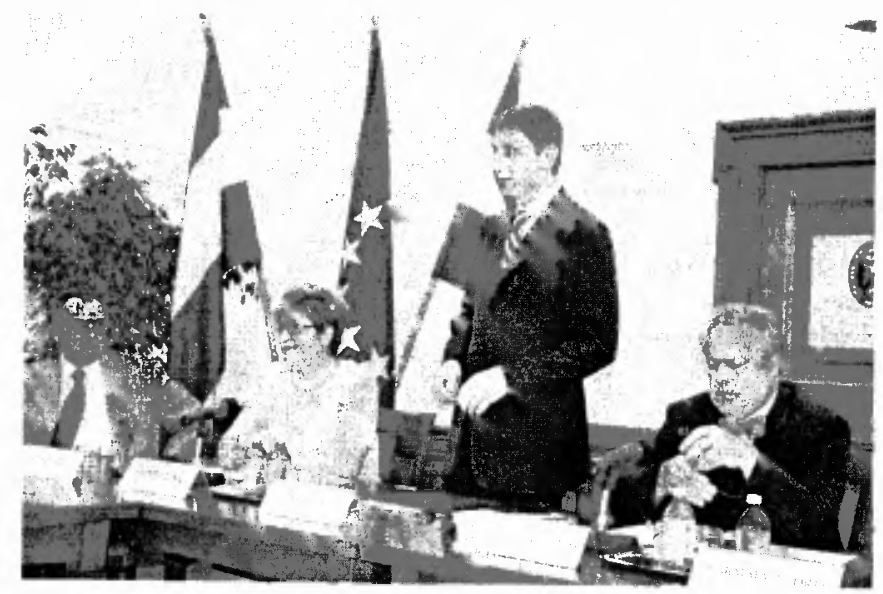

A közigazgatási átalakításról szólva Deák Ferencre utalt, aki a falu és a város együttmúködése kereteként a járást fogalmazta meg. Azóta azonban nagyot változott a világ, nagyot változtak a polgárok igényei. Ellentmondásos a feltételek sokasága. Az államra a polgárok ma már szolgáltató partnerként tekintenek, s nem a feudális alázatosság, hanem az öntudatos adófizető polgár a közigazgatás megrendelője. A szolgáltatásokhoz a polgár ma már a lehető legegyszerủbben kíván hozzáférni, viszont a központok ma már nagyon könnyen elérhetők, söt, az állam által nyújtott szolgáltatások igénybevételének ma már az államhatár sem szab gátat, példaként említve a Szlovákiából Magyarországra átjáró, s itt egészségügyi szolgáltatásokat igénybe vevők nagy számát.

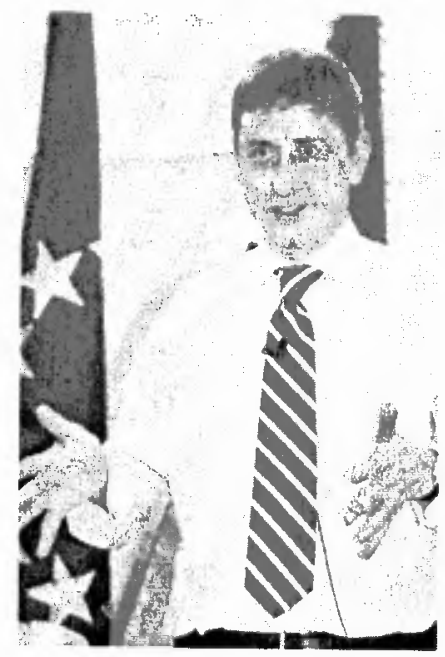


A fejlesztések szerepére utalásként megjegyezte, hogy nem egyedi elszigetelt fejlesztések tesznek bennünket alkalmassá a fejlödésre, hanem a fejlesztési forrásoknak egyszerre kell szolgálniuk több funkciót. Pl. egy városi beruházásnak kistérségi és régiós kisugárzásúnak kell lennie.

A területfejlesztés fontos gazdaságpolitikai és társadalompolitikai kihatással is bír. A nagy befektetők telephely választási döntéseit sok tényező befolyásolja, amelyek közül csak sokadikként jön számításba az adó mértéke. Fontosabb, hogy, milyenek az üzleti és közigazgatási szolgáltatások, vannak-e fejlesztési elképzelések, milyen a humán eröforrás.

Jelentősek az országban a regionális különbségek. Más fejlesztés kell a DélAlföldnek, mint Nyugat-Magyarországnak, de nem a felszínes verbalizmus szintjén, hanem konkrét cselekvések formájában. Kiemelte a települési és a regionális együttmüködések szerepét, hatékony részvételét ebben a fejlödésben.

Magyarországnak saját szolgálatába kell állítani ezt az erőforrást is: a regionalizmust és kistérségi együttmüködést, a regionális és kistérségi fejlesztést és igazgatást.

Lamperth Mónika miniszter asszony, folytatva az eddigi gondolatokat kijelentette, hogy eddig fontos eredményeket értek el a kistérségi együttmüködések terén. A kistérségi együttmüködés azonban nem helyettesítheti a regionalizmust. Nem állnak meg a tervezett reformok továbbra sem. A decentralizáció és a kistérségi intézményrendszer fejlesztése, $s$ az érdemi dereguláció, mint cél nem szünt meg. Továbbra is alapvető kérdés: milyen eszközökkel tudják a kistérségi együttmúködést fejleszteni? A fejlesztéseket nagymértékben elösegíti, hogy egy tárcánál lesz az önkormányzatok és a területfejlesztés kérdése. Így ezek a problémák nagyobb súlylyal jelennek meg a döntéshozók asztalán. A regionalizációval kapcsolatban három megoldási irányt említett. A Dél-dunántúli régió példája az egyik, ahol az önkormányzatok regionális társulása jelenti a megoldást. A területfejlesztés intézményeinek fejlesztése, a regionális területfejlesztési tanácsok átalakítása a másik lehetőség. Ehhez meg kell vizsgálni, hogy milyen résztvevőkkel, felelösséggel, feladattal kell mủködniük a jövőben ahhoz, hogy a regionalizációt erösítsék. A harmadik irány a közjogi szerződések lehetősége.

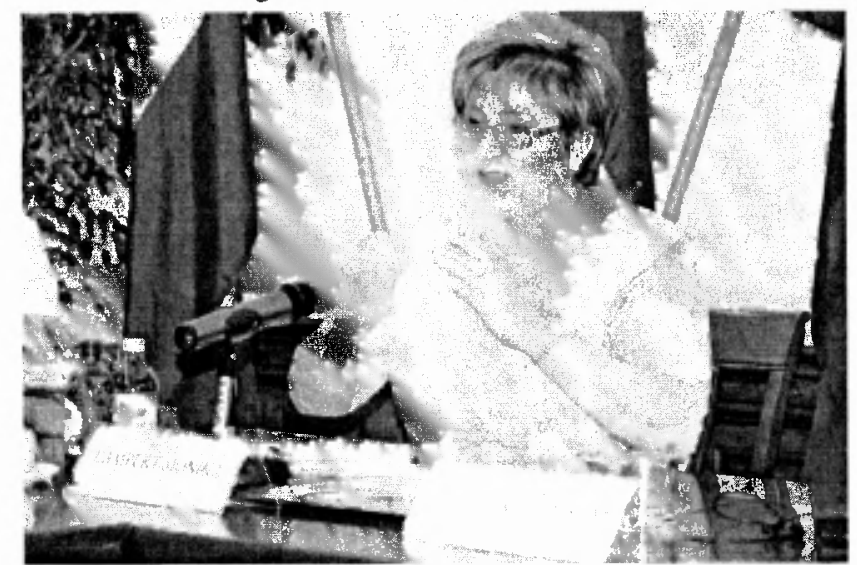


Egy új várospolitika kidolgozását is szükségesnek látja. A városhálózat fejlesztésének módozatait át kell gondolni, újra kell formálni.

A kormányzat, a tárca és tudomány együttmúködése kapcsán kiemelte a partnerség jelentőségét. Ennek egyik gyakorlati megnyilvánulásaként az IDEA program átalakításáról beszélt. Az eddig eredményes, elsősorban a közigazgatás kérdéseire koncentráló irány mellett erősíteni kell a területfejlesztés problémáinak vizsgálatát is. Új szereplök bevonásával meg kell találni az egyensúlyt az egyes témák között.

Szirmai Viktória, a gyülés másik levezetö elnöke kutatási eredményei alapján egy modern, komplex szemléletủ településfejlesztési koncepció létrehozását sürgette. Állításait egy 5 ezer fös mintán végzett kutatás eredményeivel támasztotta alá. Magyarországon egyre fontosabb települési problémává válnak a területei egyenlötelenségek, a szegregáció, város és vidék egyenlötlenség, a dzsentrifikáció és a társadalmi kiszorítás. Az európai térbeli folyamatok hazánkban is megjelennek. Meg kell vizsgálni, hogy a területfejlesztés hogyan tudja ezeket kezelni. Vizsgálati eredményei alapján kiemelte, hogy a döntések során fontos a különbözỏ érdekek felmérése és kezelése.

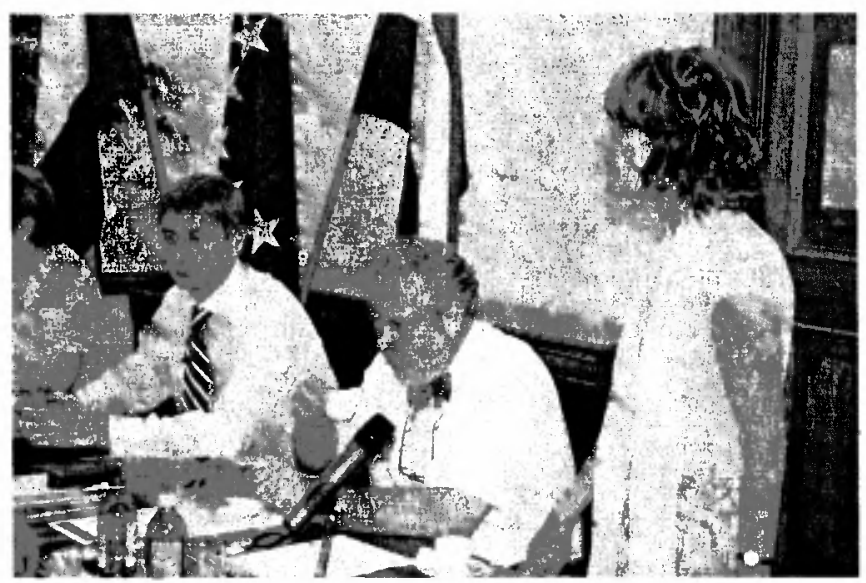

Horváth Gyula hozzászólásában bemutatta a Magyar Regionális Tudományi Társaság müködését, $s$ egyúttal utalt a regionális tudomány politikai súlyára. Hiszen a társaság gyűlései és vándorgyűlései aktuális problémákat dolgoznak fel. Megemlítette, hogy az utóbbi, a Kárpát-medence kérdéskörével foglalkozó vándorgyülésen négy ország regionális ügyekért felelös minisztere volt jelen: $\mathrm{s}$ az adott időpontban mind a négy magyar volt. Nyilatkozatot írtak alá, hogy miként lehet a Kárpátmedencét egy korszerủ európai makrorégióvá fejleszteni a regionális együttmüködésekre alapozva.

Kulcskérdés a decentralizáció, melyről sok tudományos vita folyik. A Parlamentben folyó vita lényege a regionalizmus formájáról szólt, szól. A lényeg azonban a regionalizmus tartalma. Nem közigazgatási reform miatt van szükség régiókra, hanem azért, mert a magyar térszerkezet nem korszerú. A térszerkezet korszerütlensége a gazdasági növekedés akadálya. A térstruktúra modernizálásával a gazdasági növekedés pár százalékponttal emelkedni fog. Új térformáló erőkre van szükség, s 
ezek közül a legfontosabb a gazdaság. A nyugat-európai regionális átalakulás egyik kulcsszava az újraiparosítás volt. Évek óta folyik a vita a közigazgatási kérdésekröl, a régióközpontok funkciójáról, de nincs szó arról, hogy a gazdaság müködéséhez szükséges alapvetö térformáló erök regionális lokalizációjához mire van szükség. Meröben új paradigmára, a területfejlesztési törvény alapos átalakítására van szükség. A tudomány feladata, hogy napjainkban már a 2014 és 2020 közötti időszakra tekintsen elöre, s készüijön fel rá. Ennek igazolásaként kiemelte, hogy a szakma mai eredményeiben elévülhetetlen érdemei vannak a magyar regionális tudománynak, mivel már a kilencvenes évek elején megkezdte azokat a kutatásokat, amelyeknek gyümölcse ma érik be, s országunk elökelő helyen áll ezen a téren tudományos és a szakember képzés területén is. Ez a tudás hozzájárul Magyarország versenyképességéhez. A kutatói szféra feladata, hogy olyan perspektivikus gondolkodást folytasson, amely nem a napi kényszerekre ad választ, hanem hosszabb távon gondolkodik.

A decentralizáció és regionalizáció nehézségei kapcsán megjegyezte, hogy ezekkel a problémákkal más országoknak is meg kellett küzdeniük. Azonban az integrációs feladatokat valakinek meg kell oldani, ha kell, magának az államnak. A dekoncentrált szervek, funkciók helyzetét át kell gondolni, s egy modern dekoncentrált struktúrát kell kialakítani, $s$ ennek során a regionalizmus szempontjait érvényesíteni kell. A régióközpontokba kell a regionális szerepkörủ állami szervezeteket telepíteni.

Enyedi György felszólalásában elsőként a területfejlesztési politika társadalmigazdasági kiegyenlítỏ szerepéröl beszélt. Ma már látni kell, hogy nem csak az adott állam, hanem az Európai Unió szintjén is vizsgáljuk az egyenlötlenségeket. Magyarországon nem kerülhetjük meg a kárpát-medencei kontextust sem a területi egyenlötlenségek vizsgálatánál.

A vidékfejlesztés kapesán elmondta, hogy nem szabad azt agrárproblémaként kezelni. A város és vidék fejlesztése nem választható el egymástól. Most is két tárca foglalkozik ezzel a problémakörrel. Szükséges a munkájuk összehangolása.

Harmadik megjegyzése a napjainkban sokat hivatkozott tudás alapú technológia fejlesztésére vonatkozott. Ennek elötérbe helyezése növeli a térbeli egyenlötlenséget, hiszen szükséges alapjai csak néhány városban vannak jelen Magyarországon. Hangsúlyozni kell, hogy a tudásigényesség nem mindig azonos a magas technológiával. Ösztönözni kell a nem technika igényes, de tudást kívánó ágazatok fejlesztését, amelyek a hátrányosabb helyzetü térségeinkben is eredményesek lehetnek.

A vidék problémáinak elemzését folytatva Csatári Bálint a kömyezeti problémák kérdéskörét vetette fel. Megjegyezte, hogy immár 10 éves a Corki Nyilatkozat, de a magyar állam még kísérletet sem tett arra, hogy adaptálja ennek megállapításait.

Kiemelte, hogy a kutató és fejlesztő tevékenység számára komoly problémát jelent az adatok hiánya vagy rossz struktúrája. Hiteles információk nélkül nehéz a beavatkozás.

Hegedüs József a gyenge piaci helyzetü városok problémáira hívta fel a figyelmet. Maga a probléma természetes, más országokban is megfogható jelenség. Speciális hiányosságunk, hogy máig nem tudjuk elkülöníteni (s így a támogatások odaítélésé- 
ben sem jelenik meg), hogy ez a problematikus helyzet milyen mértékben ered az adott város földrajzi elhelyezkedéséböl, illetve abból, hogy a városvezetés képtelen megoldani a strukturális problémáit, nem tud váltani.

Nem látjuk át egy sor döntés területi hatásait. Példaként a lakástámogatásra kifizetett összegeket említette, amelyek elsősorban a jobb helyzetú településekre vándoroltak.

A Miniszterelnök, lezárva az ülés első részét, s reagálva az elhangzottakra a hosszú távú tervek és a négyéves politikai ciklusok összehangolásának nehézségeiröl beszélt.

A gyülés második része Köszegfalvy György hozzászólásával kezdődött. Felhívta a figyelmet a területfejlesztési törvény átdolgozásának szükségességére, mivel annak születése, illetve módosítása óta jelentősen megváltoztak a társadalmigazdasági körülmények. Kiemelte a városhálózat bövítésének problematikáját. Jelenleg 289 városunk van, s felmerül a kérdés, hogy szükség van-e ennyire? A várossá nyilvánítások rendjét egy koncepciónak kellene megszabnia, amely figyelembe veszi a kistérségi és regionális átalakulás szükségszerüségeit.

Fontos foglalkozni továbbá a ki- és átalakuló településstruktúrákkal. Ezeket a képződményeket a jelenlegi közigazgatási struktúra nem tudja kezelni. Jelentőségük viszont növekszik, az átalakulás gyors, tehát szükség van arra, hogy a közigazgatás kistérségi és regionális átalakítása során ezekre a jelenségekre odafigyeljünk.

Faragó László az Európai Unió szemszögéböl elemezte a magyarországi helyzetet. A DG Régió képviselöi felhívták a figyelmet a hiånyosságokra. Az elmúlt években bonyolultabbá vált a magyar struktúra. Nem tisztázottak még egyes intézmények feladatai. Mindenképp az állam feladata, hogy ha nem elég erősek a régiók intézményei, erösítse meg öket.

Megjegyezte a ,pólus program” lelassulását, átalakulását is, amely pedig a városfejlesztés alapvető kérdései közé tartozik. Rámutatott, hogy az elmúlt 16 évben nem volt kormányzati várospolitika, márpedig a lisszaboni folyamat sürgeti a városok fejlesztésének és szerepének hangsúlyozását.

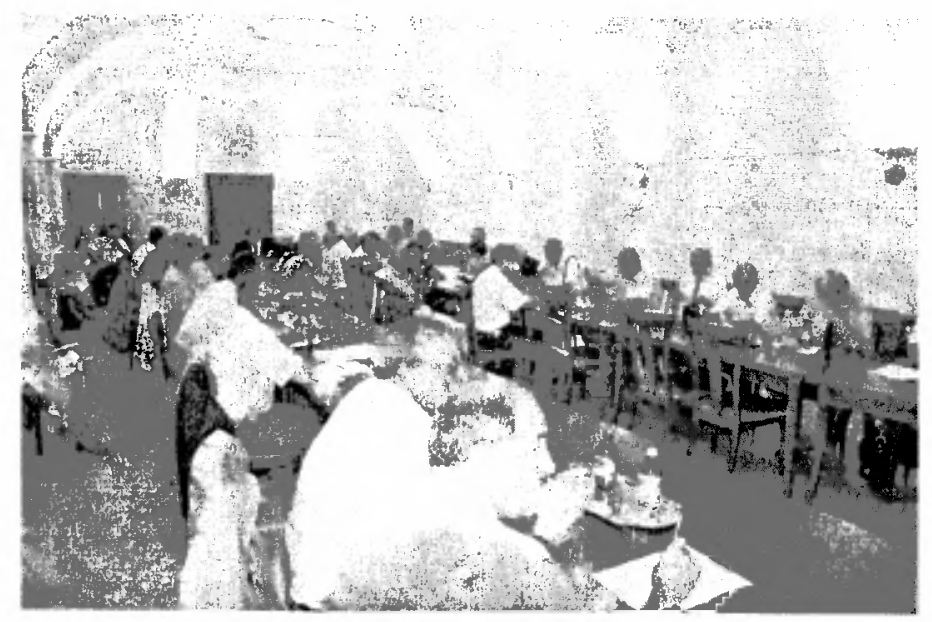


Lengyel Imre a regionális különbségeknek a növekedését elemezve három fő témára tért ki. Egyrészt változtatni kell a szemléleten, a beidegződéseken. Figyelembe kell venni, hogy a gazdasági erőforrásokért verseny van a területi egységek között, s a kiegyenlítő állami területfejlesztés nem képes gazdasági növekedést produkálni. A helyi szereplők összefogására van szükség.

Eredményes az alulról szervezödő fejlesztés. Ennek a fejlesztésnek az alapegysége a kistérségi szintủ területek lennének. Munkaerő vonzáskörzetekben kell gondolkodni, de napjainkban a lehatárolt kistérségek területe gyakran nem felel meg ezeknek a természetes körzeteknek. Az intézményi felkészültség is hiányos. Példaként a kistérségi fejlesztési tanácsokat említette, amelyekben a legtöbb esetben csak közigazgatásban dolgozó tagok ülnek, s be kellene vonni a munkaadók és munkavállalók képviselőit is a sikeres gazdaságfejlesztés érdekében.

A „pólus program” kapcsán elmondta, hogy annak jellege erősen megváltozott. A program lényege a tudásintenzív gazdaság fejlesztése (képzés, tudástranszfer stb.), $\mathrm{s}$ ezzel fejlődési pólusok létrehozása, s nem településhálózati csomópontok fejlesztése. Ez egyre inkább átalakul - egyébként hiányzó és szükséges - városfejlesztő infrastrukturális beruházásokká, s háttérbe szorul az eredeti elképzelés. Javasolja, hogy a pólusprogram irányításába minden esetben be kell vonni a képzés és a tudástranszfer, az önkormányzat és a különböző ágazati klaszterek képviselőit is.

Csemez Attila a táj megőrzésének és kezelésének fontosságát kiemelve bírálta a hazai fejlesztési gyakorlatot. Bár elvben a szabályozás jó, de a gyakorlati megvalósítás sok kívánnivalót hagy maga után. Eleve baj van a normák betartásával. Eljutottunk oda, hogy sok esetben a település rendezési, szabályozási terveket igazítják a már elkészült építményekhez, s nem fordítva.

Mészáros Rezső figyelmeztetett arra, hogy nem szabad elfelejteni, hogy a tudásalapú gazdaság fejlesztéséböl szükségszerủen kiesik egy jelentös réteg, akik korosztályuknál vagy tudásuknál fogva nem képesek bekapcsolódni az új fejlödési irányba. Kialakulhat egy szakadék, amit kezelni kell.

Bartke István a területfejlesztés irányítási rendszerének minőségi átalakításáról beszélt. A háromszintú intézményrendszer - kistérség, régió, ország - regionális szintjén az államnak kell kialakítania olyan szervezeteket, amelyek közvetlenül képesek az EU szerveivel együttmúködni, kommunikálni. A kistérségi szinten meg kell határozni a kiemelt településeket, s az intézmények létrehozása mellett meg kell teremteni azok elérhetöségét is.

Hervai Szabó Gyöngyvér szerint is új alapokra kell helyezni a fejlesztést. A hagyományos struktúra több okból sem tudja biztosítani az integrációt. Lehetséges irányként a városrégió koncepciót említette, kiegészítve egy decentralizált közigazgatási és hatósági modellel.

Baranyi Béla a határ menti periférikus térségek problémáját mutatta be. Hangsúlyozta, hogy ezek felzárkóztatása ma már elképzelhetetlen a határon átnyúló együttmúködések nélkül. Ezek az együttmüködések egyre nagyobb jelentőséget töltenek be a fejlesztésben. Jellemző rájuk, hogy egyre inkább a kisebb méretủ, térségi szintủ együttmüködések, valamint a városközi kapcsolatok hatékonysága erősödik. 
Kovács Katalin felhívta a figyelmet arra, hogy a kistérségek, vidékfejlesztési programok müködése mögött már több év áll. A továbblépés elött fontos lenne mérleget vonni: hol szorul átalakításra az eddigi modell? Alkalmas-e a kistérség az országban mindenhol egyformán a neki szánt szerep betöltésére? Külön kiemelte a térségi közlekedés problémáját. Az egy napi járás - a központok elérése - bizony nehézségekbe ütközik számos periférikus térségben. Az ingázás, a gazdasági vonzáskörzetek és kistérségi határok nem megfelelése jelentős problémája a rendszernek, s gyakran húzódik meg a tartós munkanélküliség hátterében ez a tényezö. Mindenképpen javítani kell ezeken a problémákon, például a személyszállítás javításával, a személyszállítási koncesszió átgondolásával.

Az elöre bejelentkezett hozzászólók után rövid reagálások hangzottak el több bizottsági tag részéröl is, amivel a rendelkezésre álló időkeretet a vita teljesen kitöltötte.

$\mathrm{Az}$ ülés lezárásaként Lamperth Mónika önkormányzati és területfejlesztési miniszter asszony méltatta az elhangzottakat, reagált a kiemelt pontokra. A tanácskozást hasznosnak ítélte a kormányzati munka részéröl, s javasolta a szakma és a politika szereplöinek mind intenzívebb együttmüködését is, amelyre a lezajlott bizottsági uulés kiváló példát szolgáltatott.

A miniszter asszony reagálása után Rechnitzer János elnök az ülést lezárta. 